\title{
Effect of Traditional Process Methods on the Physicochemical and Functional Properties of a Traditional Food Salt (Nikkih) Obtained from Waste Biomass Peels of Musa paradisiaca and Musa acuminate
}

\author{
Pride Ndasi Ngwasiri ${ }^{(D},{ }^{1}$ Vivian Akah Adanmengwi, ${ }^{1}$ Wilson Agwanande Ambindei, ${ }^{2}$ \\ Noumo Thierry Ngangmou, ${ }^{1}$ Dobgima John Fonmboh, ${ }^{1}$ Ngwa Martine Ngwabie, ${ }^{3}$ \\ Martin Benoit Ngassoum, ${ }^{2}$ and Ejoh Richard Aba ${ }^{1}$ \\ ${ }^{1}$ Department of Nutrition,Food and Bioresource Technology, College of Technology, The University of Bamenda, P.O. Box 39, \\ Bambili, Cameroon \\ ${ }^{2}$ Department of Process Engineering, ENSAI, University of Ngaoundere, P.O. Box 455, Ngaoundere, Cameroon \\ ${ }^{3}$ Department of Agriculture and Environmental Engineering, College of Technology, The University of Bamenda, P.O. Box 39, \\ Bambili, Cameroon
}

Correspondence should be addressed to Pride Ndasi Ngwasiri; ngwasiripridy@yahoo.com

Received 14 July 2021; Revised 14 November 2021; Accepted 16 November 2021; Published 7 December 2021

Academic Editor: Alireza Baghban

Copyright (๑) 2021 Pride Ndasi Ngwasiri et al. This is an open access article distributed under the Creative Commons Attribution License, which permits unrestricted use, distribution, and reproduction in any medium, provided the original work is properly cited.

In Cameroon, agrofood waste biomass such as peels of Musa paradisiaca and Musa acuminate is being valorized using various traditional processing methods to produce a traditional functional food salt, potash, locally called nikkih. Nikkih has been reported to have varying physicochemical and functional properties, which negatively affect the quality and stability of food prepared using it. This work aims at evaluating the effect of traditional process methods on the physicochemical and functional properties of nikkih produced from these peels in view of the optimization of the process. The peels were preprocessed using two methods: boiling at $90^{\circ} \mathrm{C}$ before drying and direct drying of raw samples. All samples were dried and combusted to ash at varying temperatures of $250^{\circ} \mathrm{C}, 300^{\circ} \mathrm{C}$, and $350^{\circ} \mathrm{C}$ and times of $30 \mathrm{~min}, 60 \mathrm{~min}$, and $90 \mathrm{~min}$. The ash obtained was dissolved in varied volumes of water, filtered to obtain the nikkih. Yellow achu soup was prepared through the dry gum method using water and read palm oil, with nikkih as emulsifier. The physicochemical and functional properties of nikkih on yellow achu soup were evaluated using standard methods. The ash yield ranged from $10.62 \pm 0.12 \%$ to $7.10 \pm 0.05 \%$, with the raw samples combusted at $300^{\circ} \mathrm{C}$ and $250^{\circ} \mathrm{C}$ having the highest and lowest values respectively. The $\mathrm{pH}$ of nikkih ranged from $10.95 \pm 0$ to $12.01 \pm 0.056$ while potash content ranged from $32.45 \pm 0.905 \%$ to $72.29 \pm 1.31 \%$, with the highest and lowest values obtained from the raw sample combusted at $250^{\circ} \mathrm{C}$ and the boiled samples combusted at $350^{\circ} \mathrm{C}$ respectively. Alkaline content ranged from $61.7 \pm 0.141 \%$ to $52.8 \pm 0.141 \%$, with boiled M. acuminate combusted at $350^{\circ} \mathrm{C}$ having the highest value and the lowest from raw M. paradisiaca combusted at $250^{\circ} \mathrm{C}$. The foaming capacity and foam stability ranged from $6.9 \pm 0.01 \%$ to $16.07 \pm 2.51 \%$ and from $3.20 \pm 0.07 \%$ to $11.205 \pm 2.39 \%$ for $M$. acuminate and $M$. paradisiaca respectively. The emulsification index ranged from $85.62 \pm 0.09 \%$ to $86.67 \pm 1.141 \%$ after $24 \mathrm{hrs}$ and from $26.0 \pm 0.94 \%$ to $27.02 \pm 2.390 \%$ after $48 \mathrm{hrs}$, with the highest value from the raw M. acuminate combusted at $350^{\circ} \mathrm{C}$ and the lowest from that combusted at $300^{\circ} \mathrm{C}$. The potash source, pretreatment method, combustion conditions, and dilution factors all had an effect on the physicochemical and functional properties of nikkih. 


\section{Introduction}

Food loss and waste is recognized as a serious threat to food security, the economy, and the environment [1]. Despite various measures taken to ensure the notion of zero waste so as to attain sustainable food production and consumption $[2,3]$, agrofood waste management still remains a serious problem in many countries $[4,5]$. The agrofood industry generates high amounts of byproducts and waste, which account for more than $50 \%$ of fresh fruit and at times have a nutritional or functional value higher than the final products [6]. These byproducts and waste, constituting mainly of peels, trimmings, stems, shells, bran, and seeds, are regarded as emerging sustainable agricultural issues as many of these biomaterials are underutilized and end up in municipal landfills where they create serious environmental, economic, and social problems [7-9]. The environmental and economic impact of agrofood waste is associated with the depletion of natural resources used for its production and the costs associated with its disposal (Moron, 2016). These two problems can be solved within the context of the circular bioeconomy by valorizing these wastes for the production of value-added biochemical products or ingredients for the agrofood industry [10, 11]. The exploitation of food byproducts and waste generated in the poor regions of the world for the formulation of novel foods or food ingredient will directly benefit the local communities [12], thereby enhancing food security and contributing to the development of the circular bioeconomy.

In many regions in Cameroon, particularly in the North West and West Regions, for example, the peels of Musa paradisiaca and Musa acuminate are being valorized traditionally for the production of a traditional functional food salt, potash, locally called 'nikkih'. Nikkih constitutes the crude brownish or blackish extract produced traditionally by leaching the ashes of combusted agrofood waste with water to obtain a potassium-carbonate-rich crude bioextract $[13,14]$. Their chemical composition shows that they are a mixture of salts and, thus, are made of cations and anions; the major cation is generally sodium or potassium whereas the major anions are generally carbonates, bicarbonates, sulfates, and chlorides [15-17]. These biobase functional plant extracts are fast replacing the common lake salt called "kangwa", as they are regarded as cheaper, safer, less-toxic, and readily available from food waste biomass and their production from waste biomass contributes to environmental protection. Nikkih is now used in the preparation of a variety of foods due to its functional properties since it serves as emulsifier, tenderizer, thickener, seasoning, potentiating adjunct, and preservative [18]. The functionalities of nikkih have been attributed to the alkalinity of the aqueous solution [19]. With respect to its functionality, the ability to reduce cooking time has been studied [20,21].

Traditionally, nikkih is produced using two methods of pretreatment of the peels of $M$. paradisiaca and $M$. acuminate: boiling of the raw peels before drying or direct drying of the peels. The drying process is followed by combustion of the biomass to produce ash and leaching of the ash with water to obtain a crude brownish or blackish extract. This potassium-carbonate-rich crude extract $[13,14]$ produced in an indigenous manner contains a lot of impurities responsible for its color [22] and has been reported to have varied functional properties when used in food as an emulsifier and stabilizer, especially in yellow achu soup. Yellow achu soup is an emulsion of crude palm oil in water, stabilized by kanwa and more recently by nikkih, in which a mixture of ground local spices is added. The soup is eaten with a traditional delicacy called achu, obtained by pounding the tubers of Colocasia esculenta. In the traditional method of nikkih production, the biomass pretreatment methods vary as a function of the source of the peels along the food value chain: boiling of the Musa sp. with peels before drying or peeling off the peels to dry directly. On the other hand, the combustion and extraction are done under undefined temperature and time process conditions.

Till date, most studies on traditional plant based food salts have been focused on their chemical composition $[23,24]$, their effect on the nutritional quality of foodstuffs $[19,25,26]$, their effect on the taste of food preparations [19], and their toxicological effect $[12,27]$. The variability and functionalities of traditional salts used in traditional African food preparations were studied by Ngoualem et al. [28] while Ngwasiri et al. [29] studied the effect of the incorporation of crude extract from Ficus carica seed peels into crude extract from plantain peel ash to improve on its functional properties and the sensory properties of the yellow achu soup. Furthermore, Franklin et al. [30] reviewed the chemistry and functionalities of lake deposits and plant-based salts used in food preparations. All these studies basically highlighted the relationships among chemical composition and physicochemical properties of traditional alkaline salts when used in solution as well as their functionalities. Studies attempting to evaluate the effect of the traditional process methods on the physicochemical and functional properties of this traditional food salt are very scarce.

The physicochemical and functional properties of traditional plant based food salt seem to be related to the nature of plants used for their preparation and the biomass processing conditions [31]. There are numerous reports of ash salts having been produced all over South and Central America [32] and in Africa, including Cameroon [30], but reports on the effect of processing methods on the physicochemical and functional properties of this traditional food salt are scarce. Processing factors such as the number of cycles and duration of filtration have been reported to affect some properties of the salt such as its color [30]. In addition, the degree of compaction of banana/plantain peels and stalks during combustion has been reported to determine the color of the salts: green with low compaction or black or white with high compaction. Phanice et al. [33] reported the effect of the transformation, preparation method, storage conditions, and time on Iodine and Iron (II) present in Reed Salt, a traditional plant based salt in Kenya. The valorization of these biomass into quality and safe functional traditional food salt as such faces a certain number of problems like differences in the biomass pretreatment methods, boiling of biomass before drying and direct drying of biomass, and the combustion conditions. 
Biomass pretreatment and the different process conditions during the thermochemical process, such as temperature, reaction time, heating rate, and pressure, have been reported to affect the quality of intermediates and the products generated [34]. Currently there are scarcity of information on the effect of the traditional pretreatment and processing methods used for nikkih production on its functional quality and the sensory property of yellow achu soup. From these findings, checking the influence of the process method and process factors on the physicochemical and functional properties of traditional food salts appears as research questionable issues. This will help in the determination of the best process conditions for the production of nikkih with optimal functional and sensory qualities. This research is therefore aimed at studying the effect of the two traditional process methods on the physicochemical and functional properties of food grade lime (nikkih) obtained from waste biomass peels of Musa paradisiaca and Musa acuminate.

\section{Materials and Methods}

2.1. Materials for Nikkih and Yellow Achu Soup Preparation. Fresh unripe Musa paradisiaca and Musa acuminate peels were obtained from a local market in Bambili-Bamenda and transported to the laboratory in a flask at $4^{0} \mathrm{C}$ where it was stored in a refrigerator at $4^{0} \mathrm{C}$ before usage so as to avoid any ripening. Red palm oil and all other spices for the preparation of the yellow achu soup were obtained from the Bambili market.

\subsection{Pretreatment of Musa paradisiaca and Musa acuminate} Peels. The waste biomass peels were pretreated following the two traditional methods commonly applied in the North West region of Cameroon. Unripe Musa paradisiaca and Musa acuminate peels were washed with clean running tap water to remove all debris. The peels were separated into two portions each, which were subjected to two pretreatment methods as locally done, before drying and combustion to produce ash. One portion of the peels from Musa paradisiaca and Musa acuminate was maintained raw (RS) while the second portion was boiled (BS) for 90 mins at $90^{\circ} \mathrm{C}$. This was followed by drying of all the portions separately in a food dehydrator at $70^{\circ} \mathrm{C}$ for $48 \mathrm{hrs}$. The dried peels were weighed and stored in dry airtight polyethylene bags for further processing.

2.3. Combustion of Musa paradisiaca and Musa acuminate Peels for Ash Production. The waste biomass peels were combusted following the traditional method commonly applied in the North West region of Cameroon, with a variation of the combustion temperature and time. A known weight of the pretreated dried $M$. paradisiaca and M. acuminate peels was combusted in a furnace to ash using different combustion temperature-time combination of $250^{\circ} \mathrm{C}, 300^{\circ} \mathrm{C}$, and $350^{\circ} \mathrm{C}$ for $30 \mathrm{mins}, 60 \mathrm{mins}$, and $90 \mathrm{mins}$, respectively. The ash was then collected, weighed, and stored in dried airtight containers for further processing and analyses.
2.4. Preparation of the Liquid Extract (Nikkih). The liquid crude extract from the ashes of $M$. paradisiaca and M. acuminate peels was produced as described by Kumar [35] and illustrated in Figure $1.100 \mathrm{~g}$ of the ashes was weighed and placed in separate bottles and varied volumes of water of $500 \mathrm{ml}, 1000 \mathrm{ml}$, and $1500 \mathrm{ml}$ at $80^{\circ} \mathrm{C}$ were measured and poured in the respective bottles. The bottles were corked, mixed vigorously, and allowed to stand for 12 hours. The resulting clear liquid solution was filtered into well labelled plastic bottles using Whatman $\mathrm{N}^{\circ}$. 41 filter paper.

2.5. Experimental Design. The custom screening design was used to carry out the experiment. The four traditional process parameters evaluated were the pretreatment of the waste biomass (peel), the combustion time and temperature and the dilution/extraction volume. The two pretreatments consisted of using raw M. paradisiaca and M. acuminate peels noted as RwMp and RwMa and the heat treated (boiled peels) at $90^{\circ} \mathrm{C}$ noted as $\mathrm{Mp} 90$ and Ma90 respectively. A commercial sample, $X$ (com), was used as the control. An experimental matrix with 13 runs and 6 responses was generated as presented in Table 1 using the Custom Design from JMP.

2.6. Preparation of Yellow (Achu) Soup. The achu soup was prepared using the traditional dry gum method as presented in Figure 2. In the dry gum method, the emulsifying agent is mixed with the red palm oil before the addition of water to form the emulsion. The red palm oil was heated for $1 \mathrm{~min}$ and $20 \mathrm{ml}$ was measured and poured into separate bowls. $10 \mathrm{ml}$ of the nikkih, acting as the emulsifier (nikkih), and $1 / 2$ teaspoon of achu spices were then added to each bow followed by $50 \mathrm{ml}$ of hot water at $80^{\circ} \mathrm{C}$. The mixture was stirred thoroughly to form a homogenous mixture.

\subsection{Physicochemical Analysis}

2.7.1. Determination of Ash Yield of the Biomass. The ash content is defined as the inorganic residue that remained after the organic matter was burnt away. The ash yield was determined volumetrically as described by Vladimir [36]. A known weight (M1) of each oven-dried sample was ashed in a furnace at $600^{\circ} \mathrm{C}$. The ashed samples were allowed to cool and the final weight (M2) was determined using an electronic balance. The ash content was calculated using the formula below:

$$
\text { Ash yield }=\frac{M 2}{M 1} \times 100 \text {. }
$$

2.7.2. Determination of $\mathrm{pH}$ Value. The $\mathrm{pH}$ of the extracts was determined using Apera instruments, pH700 pH meter following standard analytical method. The $\mathrm{pH}$ meter was calibrated using buffer solutions of $\mathrm{pH} \mathrm{7,} \mathrm{the} \mathrm{pH}$ of each extract subsequently determined. The results were recorded in duplicate. 


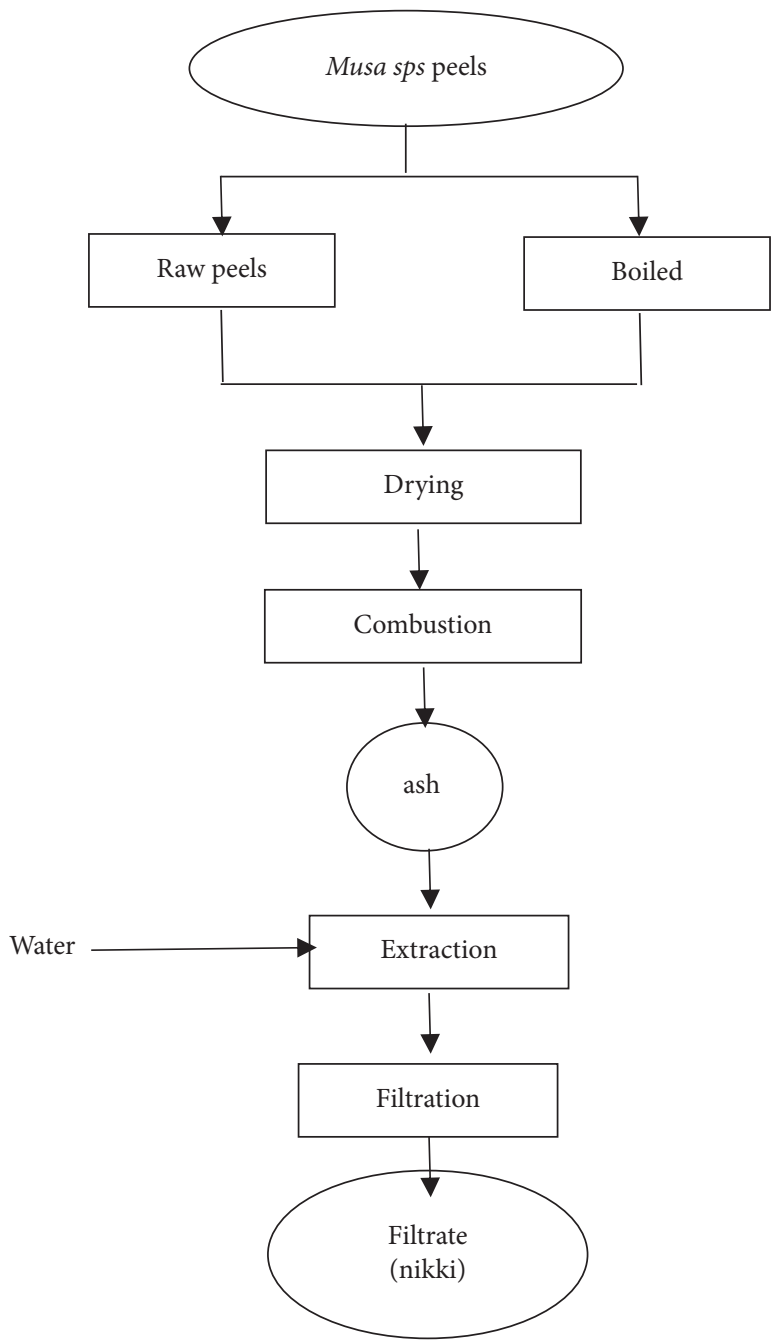

Figure 1: Synoptic diagram of the traditional preparation of plant based ash solution (nikkih).

TABle 1: Custom design experimental matrix for study of effect of process parameters on quality of potash from $M$. paradisiaca and M. acuminate peels.

\begin{tabular}{|c|c|c|c|c|c|c|c|c|c|}
\hline \multicolumn{4}{|c|}{ Experimental factors } & \multicolumn{6}{|c|}{ Responses } \\
\hline $\begin{array}{l}\text { Potash } \\
\text { source }\end{array}$ & $\begin{array}{l}\text { Burning } \\
\text { time (min) }\end{array}$ & $\begin{array}{l}\text { Burning } \\
\text { temp }\left({ }^{\circ} \mathrm{C}\right)\end{array}$ & $\begin{array}{l}\text { Dilution } \\
(\mathrm{mL})\end{array}$ & $p \mathrm{H}$ & $\begin{array}{c}\text { Ash } \\
\text { content } \\
(\%)\end{array}$ & $\begin{array}{c}\text { Potash } \\
\text { content (\%) }\end{array}$ & $\begin{array}{l}\text { EI ( } 24 \mathrm{hrs} / \\
48 \mathrm{hrs})(\%)\end{array}$ & $\begin{array}{c}\text { Alkali content/ } \\
\text { nonalkali }(\%)\end{array}$ & $\begin{array}{c}\text { Foam capacity/ } \\
\text { foam stability (\%) }\end{array}$ \\
\hline $\mathrm{RwPt}$ & 30 & 350 & 500 & & & & & & \\
\hline RwBa & 30 & 300 & 1500 & & & & & & \\
\hline RwBa & 60 & 350 & 1000 & & & & & & \\
\hline Pt90 & 90 & 350 & 500 & & & & & & \\
\hline Pt90 & 30 & 300 & 1500 & & & & & & \\
\hline $\mathrm{Ba} 90$ & 30 & 250 & 1000 & & & & & & \\
\hline $\mathrm{RwPt}$ & 90 & 300 & 1000 & & & & & & \\
\hline Pt90 & 60 & 250 & 1000 & & & & & & \\
\hline Ba90 & 60 & 300 & 500 & & & & & & \\
\hline $\mathrm{RwBa}$ & 90 & 250 & 500 & & & & & & \\
\hline $\mathrm{Ba} 90$ & 90 & 350 & 1500 & & & & & & \\
\hline $\mathrm{RwPt}$ & 60 & 250 & 1500 & & & & & & \\
\hline Com & & & & & & & & & \\
\hline
\end{tabular}




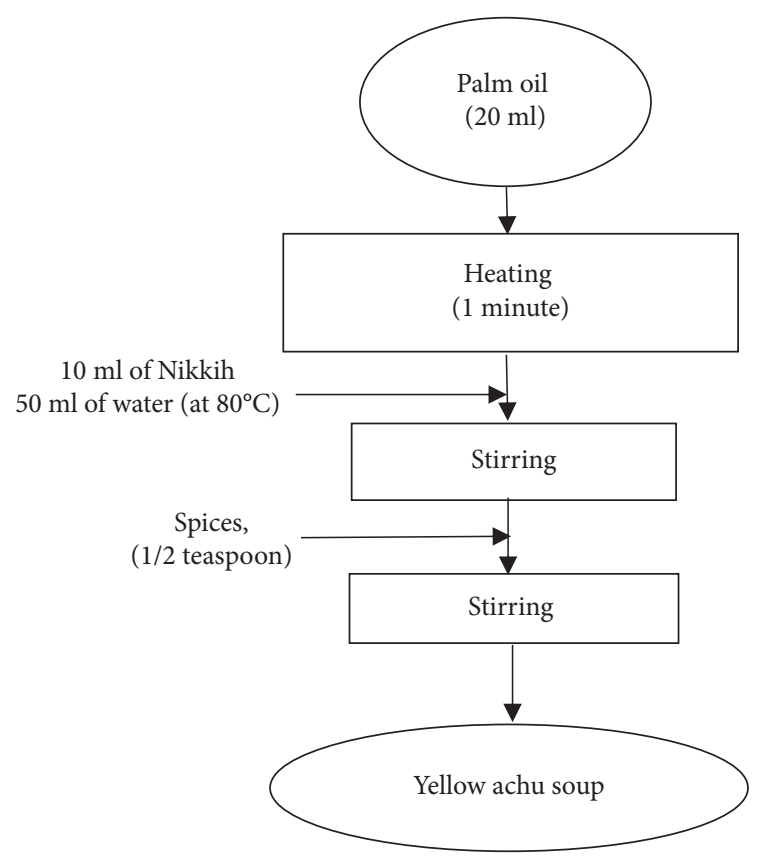

FIGURE 2: Synoptic diagram presenting the preparation of yellow achu soup using the produced potash.

\subsubsection{Determination of Potash and Nonpotash Content of the} Extract. Potash content refers to the water-soluble content of the residue obtained after complete evaporation of the extract solution leached from ashes. The potash content was determined as described by Babayemi [37]. A known weight of the peels was completely combusted to ash and a known weight of the ash (W1) leached with a known volume of water (V) to obtain a solution containing water-soluble inorganic compounds. The resulting potash was obtained in a dry form by evaporating the leachate to complete dryness and drying the residue to constant weight (W2) in an oven at $105^{\circ} \mathrm{C}$. After evaporation of volume $\mathrm{V} 1$ of water, the potash content (PCa) (\% of ash) was derived using (2) while (3) was used for the nonpotash content (NPCa) (\% of ash):

$$
\begin{aligned}
\mathrm{PCa} & =\left[\frac{\mathrm{w} 2}{\mathrm{v} 1} \times v\right] \times \frac{1}{w 1} \times 100, \\
\mathrm{NPCa} & =100-\left[\frac{\mathrm{w} 2}{\mathrm{v} 1} \times v\right] \times \frac{1}{w 1} \times 100 .
\end{aligned}
$$

2.7.4. Determination of Alkali Content and Nonalkali Content of Potash. The alkali content of potash consists of the potassium and/or sodium carbonates. The total alkali content was determined by acid-base titrimetry, using methyl orange and/or phenolphthalein indicator(s) as described by Adewuyi et al. [13]. A known weight (2 g) of the solid potash of each sample was dissolved in distilled water in a $250 \mathrm{ml}$ volumetric flask. $25 \mathrm{ml}$ of the solution was pipetted and titrated against $0.1 \mathrm{M} \mathrm{HCl}$ using methyl orange indicator for the determination of total alkaline content while the phenolphthalein indicator was used for the determination of the hydroxide content. Analyses were carried out in replicates and the average titres were used to calculate the alkali content of the crude potash.

$$
\begin{aligned}
& \mathrm{K}_{2} \mathrm{CO}_{3(\mathrm{aq})}+2 \mathrm{HCl}_{(\mathrm{aq})} \longrightarrow 2 \mathrm{KCl}_{(\mathrm{aq})}+\mathrm{CO}_{2(\mathrm{~g})}+\mathrm{H}_{2} \mathrm{O}_{(\mathrm{l})} \\
& \text { or } \\
& \mathrm{NaCO}_{3(\mathrm{aq})}+2 \mathrm{HCl}_{(\mathrm{aq})} \longrightarrow 2 \mathrm{NaCl}_{(\mathrm{aq})}+\mathrm{CO}_{2(\mathrm{~g})}+\mathrm{H}_{2} \mathrm{O}_{(\mathrm{l})} .
\end{aligned}
$$

\subsection{Determination of the Functional Properties of Nikkih}

2.8.1. Calculation of Foaming Capacity and Foam Stability. The effect of nikkih on the foaming capacity and foam stability of the yellow achu soup was analyzed as described by Liu et al. [38], with slight modifications. $10 \mathrm{ml}$ of each of the prepared yellow achu soup samples was placed in test tubes. For the determination of the foaming capacity, the initial total height of the mixture, $\mathrm{B}$ in $\mathrm{cm}$, was registered. The mixture was then whipped for 30 mins and the total height, $\mathrm{A}$ in $\mathrm{cm}$, noted. The foaming capacity was calculated using (4). The whipped samples were allowed to stand for 3 minutes, the height, $\mathrm{C}$ in $\mathrm{cm}$, recorded and the foaming stability calculated using (5):

$$
\begin{aligned}
& \text { Foam capacity }(\%)=\frac{(A-B)}{B} \times 100, \\
& \text { Foam stability }(\%)=\frac{A-C}{C} \times 100 .
\end{aligned}
$$

2.8.2. Calculation of Emulsification Index. The emulsifying activity of the different nikkih samples used in the preparation of yellow achu soup was evaluated as described by McClements [39] with slight modifications.10 $\mathrm{ml}$ of the seven samples of yellow achu soup obtained was placed in different test tubes, vortexed at high speed, and allowed to stand. The production of creamy emulsion was observed at time intervals of 24 hours and 48 hours and the emulsification index (EI) calculated using

$$
E I=\frac{\text { height of the emulsified layer }}{\text { total height of emulsion }} \times 100 \text {. }
$$

2.9. Statistical Analysis. All analysis was carried out in duplicates and their average was calculated. The data were analyzed using JMP (Jump) statistical software and Microsoft Excel.

\section{Results}

\subsection{Effect of Processing Method on the Physicochemical Properties of Nikkih}

3.1.1. Variation of Ash Yield. The values for the ash yield ranged from $6.89 \pm 0.05 \%$ to $10.62 \pm 0.12 \%$ as shown in Table 2, with $M$. acuminate having higher values compared to $M$. paradisiaca. The raw $M$. acuminate samples had the highest ash yield compared to the boiled samples, with RwMa combusted at $300^{\circ} \mathrm{C}$ for $30 \mathrm{~min}$ having the highest percentage ash yield of $10.62 \pm 0.12 \%$ while that combusted at $250^{\circ} \mathrm{C}$ for $90 \mathrm{~min}$ had the lowest of $7.37 \pm 0.04 \%$. 
TABle 2: Percentage of ash yield from M. acuminate and $M$. paradisiaca peel biomass as a function of process conditions.

\begin{tabular}{lccc}
\hline Biomass treatment process method & Combustion time $(\mathrm{min})$ & Burning temp $\left({ }^{\circ} \mathrm{C}\right)$ & Ash yield $(\%)$ \\
\hline RwMp & 30 & 350 & $8.89 \pm 0.04$ \\
RwMa & 30 & 300 & $10.62 \pm 0.12$ \\
RwMa & 60 & 350 & $8.23 \pm 0.05$ \\
Mp90 & 90 & 350 & $7.90 \pm 0.04$ \\
Mp90 & 30 & 300 & $8.59 \pm 0.08$ \\
Ma90 & 30 & 250 & $7.89 \pm 0.05$ \\
RwMp & 90 & 300 & $7.73 \pm 0.29$ \\
Mp90 & 60 & 250 & $7.35 \pm 0.26$ \\
Ma90 & 60 & 300 & $7.38 \pm 0.04$ \\
RwMa & 90 & 250 & $7.37 \pm 0.04$ \\
Ma90 & 90 & 350 & $7.10 \pm 0.05$ \\
RwMp & 60 & 250 & $9.27 \pm 0.07$ \\
\hline
\end{tabular}

The result represents the mean of three readings \pm standard deviation.

\subsubsection{Effect of Biomass Treatment Method on Crude Extract} $p H$. The $\mathrm{pH}$ obtained for all samples and treatments ranged from 10.95 to 12.04 as presented in Table 3, which confirmed the alkali production from both $M$. acuminate and M. paradisiaca under different biomass pretreatment and combustion conditions. This suggests good alkalinity in the production of an emulsion base from these agrofood wastes required for yellow achu soup. As observed with the case of ash yield, the raw M. acuminate (RwMa) had a higher alkalinity, with sample RwBa combusted at $250^{\circ} \mathrm{C}$ for 90 mins having the highest value of $12.01 \pm 0.05$ while RwMa combusted at $300^{\circ} \mathrm{C}$ for 30 mins having the lowest $\mathrm{pH}$ value of $10.95 \pm 0$.

3.1.3. Variation of Potash Content as a Function of M. acuminate and M. paradisiaca Peel Biomass Treatment Method. The potash content ranged from $31.81 \%$ to $72.01 \%$ as presented in Table 4. Generally, $M$. paradisiaca had a higher potash content than $M$. acuminate, with the raw sample having the highest potash content. The raw M. paradisiaca sample, RwMp, combusted at $250^{\circ} \mathrm{C}$ for 60 mins had the highest potash content of $72.81 \pm 1.13$ while the boiled M. acuminate combusted at $350^{\circ} \mathrm{C}$ for $90 \mathrm{mins}$ had the lowest of $32.45 \pm 0.90$.

3.1.4. Variation of Alkali Content and Nonalkali Content of Potash. The alkali content ranged from $52.8 \pm 0.14 \%$ to $61.7 \pm 0.14 \%$, while the nonalkali content ranged from $38.3 \pm 0.14 \%$ to $47.2 \pm 0.14 \%$ as presented in Table 5. The M. paradisiaca had a higher alkaline content than M. acuminate, with the boiled sample, Mp90 combusted at $350^{\circ} \mathrm{C}$ for 90 mins having the highest alkali content while the raw $M$. acuminate sample RwMa combusted at $250^{\circ} \mathrm{C}$ for 90 mins had the lowest value of $52.8 \pm 0.141$. On the other hand, $M$. acuminate gave a higher nonalkali content with the raw sample RwMp combusted at $250^{\circ} \mathrm{C}$ for 90 mins having the highest nonalkali content while boiled $M$. paradisiaca sample, Mp90, combusted at $350^{\circ} \mathrm{C}$ for $90 \mathrm{mins}$ had the lowest nonalkaline content of $38.3 \pm 0.14$. The alkaline contents of all the samples were higher than that of the commercial control sample while the nonalkaline contents were lower than the control sample, which had a value of $48.7 \pm 0$ and $51.3 \pm 0$ respectively.

\subsection{Effect of Processing Method on the Functional Properties of Nikkih}

3.2.1. Emulsification Index $24 \mathrm{hrs}$ and Emulsification Index $48 \mathrm{hrs}$. The results obtained for emulsification index $24 \mathrm{hrs}$ and emulsification index $48 \mathrm{hrs}$ are found in Table 6. Sample RwMp at $350^{\circ} \mathrm{C}$ displayed the highest emulsifying activity after 24 hours with a value of $86.67 \pm 1.141 \%$. Even after 48 hours, its emulsifying activity remains the highest with a value of $85.62 \pm 0.0968 \%$. Sample RwMp at $300^{\circ} \mathrm{C}$ had the lowest emulsifying activity even after 48 hours with a value of $27.02 \pm 2.390 \%$ and $26.0 \pm 0.947 \%$ after 24 hours and 48 hours respectively.

3.2.2. Foam Capacity and Foam Stability. The results recorded for the foam capacity and foam stability are shown in Table 7. It was observed that the values of foaming capacity were higher than those of foaming stability with respect to the raw material. The foam capacity ranged from $6.9 \pm 0.01 \%$ to $21.05 \pm 0.52 \%$, sample RwMa at $250^{\circ} \mathrm{C}$ had the highest foaming capacity, and sample $\mathrm{Mp} 90$ at $300^{\circ} \mathrm{C}$ had the lowest. Foam stability ranged from $3.20 \pm 0.07 \%$ to $11.205 \pm 2.39 \%$, and sample RwMa at $300^{\circ} \mathrm{C}$ had the highest foaming stability, while sample $\mathrm{RwMp}$ at $350^{\circ} \mathrm{C}$ had the lowest value.

\section{Discussion}

Combustion of biomass produces biomass ashes. Ash content and behavior during combustion are particularly important in regard to biomass fuels [40]. The results indicated that the ash content is significantly influenced by potash source, as well as the biomass pretreatment method, burning temperature, and burning time $(P<0.05)$. Generally, from Table 2, it was observed that the ash yield decreased with increase in burning temperature and burning time with respect to material. Similar results were obtained for combustion of banana peel biomass [41] and molasses [42]. This can be explained by the fact that the total amount of biomass 
TABLE 3: $\mathrm{pH}$ of potash as a function of $M$. acuminate and $M$. paradisiaca peel biomass treatment method.

\begin{tabular}{|c|c|c|c|c|}
\hline Biomass treatment method & Combustion time (min) & Combustion temp $\left({ }^{\circ} \mathrm{c}\right)$ & Dilution $(\mathrm{mL})$ & $\mathrm{pH}$ values \\
\hline RwMp & 30 & 350 & 500 & $11.74 \pm 0.01$ \\
\hline RwMa & 30 & 300 & 1500 & $10.95 \pm 0$ \\
\hline RwMa & 60 & 350 & 1000 & $11.98 \pm 0.04$ \\
\hline Mp90 & 90 & 350 & 500 & $11.17 \pm 0.19$ \\
\hline Mp90 & 30 & 300 & 1500 & $11.475 \pm 0.07$ \\
\hline Ma90 & 30 & 250 & 1000 & $11.25 \pm 0.15$ \\
\hline RwMp & 90 & 300 & 1000 & $11.565 \pm 0.43$ \\
\hline Mp90 & 60 & 250 & 1000 & $11.75 \pm 0.01$ \\
\hline Ma90 & 60 & 300 & 500 & $11.62 \pm 0$ \\
\hline RwMa & 90 & 250 & 500 & $12.01 \pm 0.05$ \\
\hline Ma90 & 90 & 350 & 1500 & $11.13 \pm 0$ \\
\hline RwMp & 60 & 250 & 1500 & $11.735 \pm 0.20$ \\
\hline Com & & & & $13.04 \pm 0.04$ \\
\hline
\end{tabular}

The result represents the mean of three readings \pm standard deviation.

TABle 4: Potash content as a function of M. acuminate and M. paradisiaca peel biomass pretreatment and combustion conditions.

\begin{tabular}{|c|c|c|c|c|}
\hline Biomass treatment method & Combustion time (min) & Combustion temp $\left({ }^{\circ} \mathrm{c}\right)$ & Dilution $(\mathrm{mL})$ & Potash content $(\%)$ \\
\hline RwMp & 30 & 350 & 500 & $61.82 \pm 0.43$ \\
\hline RwMa & 30 & 300 & 1500 & $39.38 \pm 1.23$ \\
\hline RwMa & 60 & 350 & 1000 & $39.96 \pm 0.82$ \\
\hline Mp90 & 90 & 350 & 500 & $43.01 \pm 1.41$ \\
\hline Mp90 & 30 & 300 & 1500 & $51.67 \pm 2.34$ \\
\hline Ma90 & 30 & 250 & 1000 & $48.13 \pm 2.65$ \\
\hline RwMp & 90 & 300 & 1000 & $54.085 \pm 1.09$ \\
\hline Mp90 & 60 & 250 & 1000 & $51.905 \pm 0.67$ \\
\hline Ma90 & 60 & 300 & 500 & $36.36 \pm 0.35$ \\
\hline RwMa & 90 & 250 & 500 & $48.275 \pm 1.95$ \\
\hline Ma90 & 90 & 350 & 1500 & $32.45 \pm 0.90$ \\
\hline RwMp & 60 & 250 & 1500 & $72.81 \pm 1.13$ \\
\hline Com & & & & $35.42 \pm 7.15$ \\
\hline
\end{tabular}

The result represents the mean of three readings \pm standard deviation.

TABLE 5: Alkaline content of potash as a function of $M$. acuminate and $M$. paradisiaca peel biomass pretreatment and combustion conditions.

\begin{tabular}{lccccc}
\hline Biomass treatment method & Combustion time $(\mathrm{min})$ & Combustion temp $\left({ }^{\circ} \mathrm{c}\right)$ & Dilution $(\mathrm{mL})$ & Alkaline cont $(\%)$ & Nonalkaline cont $(\%)$ \\
\hline RwMp & 30 & 350 & 500 & $58.5 \pm 0.14$ & $41.5 \pm 0.14$ \\
RwMa & 30 & 300 & 1500 & $58.1 \pm 0$ & $41.9 \pm 0$ \\
RwMa & 60 & 350 & 1000 & $59.1 \pm 0$ & $40.9 \pm 0$ \\
Mp90 & 90 & 350 & 500 & $61.7 \pm 0.14$ & $38.3 \pm 0.14$ \\
Mp90 & 30 & 300 & 1500 & $57.1 \pm 0$ & $42.9 \pm 0$ \\
Ma90 & 30 & 250 & 1000 & $56.25 \pm 0.21$ & $43.75 \pm 0.21$ \\
RwMp & 90 & 300 & 1000 & $57.4 \pm 0$ & $42.6 \pm 0$ \\
Mp90 & 60 & 250 & 1000 & $53.45 \pm 0.20$ & $46.55 \pm 0.21$ \\
Ma90 & 60 & 250 & 500 & $60.25 \pm 0.21$ & $39.75 \pm 0.14$ \\
RwMa & 90 & 350 & 500 & $52.8 \pm 0.14$ & $47.2 \pm 0.14$ \\
Ma90 & 90 & 250 & 1500 & $60.45 \pm 0.14$ & $39.65 \pm 0.21$ \\
RwMp & 60 & & & $54.4 \pm 0.14$ & $45.6 \pm 0.14$ \\
Com & & & & $48.7 \pm 0$ & $51.3 \pm 0$ \\
\hline
\end{tabular}

The result represents the mean of three readings \pm standard deviation.

ashes obtained from combustion is variable depending on the type of material and combustion process [43]. At high burning temperature and burning time more minerals are lost as the sample approaches complete combustion; hence, there is a decrease in mass. Ashing at low temperatures and short times may fail to combust all the organic matter, whereas higher temperatures may cause dehydration of structural hydroxyl groups of minerals in the peels [44].

The observed $\mathrm{pH}$ values, which ranged from 10.95 to 12.04, are in agreement with the findings by Gopalakrishna [45] and Mianpeurem et al. [16] who found the $\mathrm{pH}$ of traditional vegetable salts of Papua New Guinea to be highly 
TABLE 6: Emulsification index (EI24 hrs and EI48 hrs) of potash on yellow achu soup as a function of M. acuminate and M. paradisiaca peel biomass pretreatment and process conditions.

\begin{tabular}{|c|c|c|c|c|c|}
\hline Biomass treatment method & Combustion time (min) & Combustion temp $\left({ }^{\circ} \mathrm{C}\right)$ & Dilution $(\mathrm{mL})$ & EI $24 \mathrm{hrs}(\%)$ & EI 48 hrs (\%) \\
\hline RwMp & 30 & 350 & 500 & $86.67 \pm 1.14$ & $85.62 \pm 0.09$ \\
\hline RwMa & 30 & 300 & 1500 & $71.83 \pm 1.99$ & $70.13 \pm 0.98$ \\
\hline RwMa & 60 & 350 & 1000 & $80.38 \pm 0.89$ & $78.48 \pm 1.78$ \\
\hline Mp90 & 90 & 350 & 500 & $83.45 \pm 1.78$ & $82.11 \pm 1.73$ \\
\hline Mp90 & 30 & 300 & 1500 & $50.0 \pm 2.02$ & $46.43 \pm 1.03$ \\
\hline Ma90 & 30 & 250 & 1000 & $70.205 \pm 0.65$ & $65.92 \pm 2.05$ \\
\hline RwMp & 90 & 300 & 1000 & $27.02 \pm 2.39$ & $26.0 \pm 0.94$ \\
\hline Mp90 & 60 & 250 & 1000 & $31.23 \pm 0.95$ & $28.73 \pm 2.40$ \\
\hline Ma90 & 60 & 300 & 500 & $30.28 \pm 0.99$ & $27.46 \pm 0.95$ \\
\hline RwMa & 90 & 250 & 500 & $34.0 \pm 0.64$ & $33.38 \pm 0.56$ \\
\hline Ma90 & 90 & 350 & 1500 & $52.73 \pm 0.96$ & $49.32 \pm 0.03$ \\
\hline RwMp & 60 & 250 & 1500 & $69.8 \pm 0.66$ & $68.0 \pm 1.88$ \\
\hline Com & & & & $82.03 \pm 1.85$ & $79.49 \pm 0.73$ \\
\hline
\end{tabular}

The result represents the mean of three readings \pm standard deviation.

TABLE 7: Foam capacity and foam stability of potash on yellow achu soup as a function of M. acuminate and M. paradisiaca peel biomass pretreatment and process conditions.

\begin{tabular}{|c|c|c|c|c|c|}
\hline Biomass treatment method & Combustion time (min) & Combustion temp $\left({ }^{\circ} \mathrm{C}\right)$ & Dilution $(\mathrm{mL})$ & Foam capacity (\%) & Foam stability (\%) \\
\hline RwMp & 30 & 350 & 500 & $8.06 \pm 2.28$ & $3.20 \pm 0.07$ \\
\hline RwMa & 30 & 300 & 1500 & $11.29 \pm 2.28$ & $11.205 \pm 2.39$ \\
\hline RwMa & 60 & 350 & 1000 & $7.57 \pm 2.14$ & $4.545 \pm 2.14$ \\
\hline Mp90 & 90 & 350 & 500 & $12.86 \pm 2.02$ & $7.14 \pm 2.02$ \\
\hline Mp90 & 30 & 300 & 1500 & $6.9 \pm 0.01$ & $3.345 \pm 0.07$ \\
\hline Ma90 & 30 & 250 & 1000 & $7.16 \pm 0.34$ & $5.175 \pm 2.45$ \\
\hline RwMp & 90 & 300 & 1000 & $7.32 \pm 1.77$ & $5.71 \pm 0$ \\
\hline Mp90 & 60 & 250 & 1000 & $15 \pm 2.36$ & $8.345 \pm 2.36$ \\
\hline Ma90 & 60 & 300 & 500 & $16.07 \pm 2.51$ & $10.66 \pm 0.07$ \\
\hline RwMa & 90 & 250 & 500 & $21.05 \pm 0.52$ & $8.465 \pm 2.33$ \\
\hline Ma90 & 90 & 350 & 1500 & $12.04 \pm 6.54$ & $3.385 \pm 0.09$ \\
\hline RwMp & 60 & 250 & 1500 & $15 \pm 2.36$ & $8.34 \pm 2.36$ \\
\hline Com & & & & $12.06 \pm 2.43$ & $6.79 \pm 0.16$ \\
\hline
\end{tabular}

The result represents the mean of three readings \pm standard deviation.

alkaline, ranging from 9.2 to 10.1 for seven types of salts. Mianpeurem et al. [16] observed an alkaline $\mathrm{pH}$ for salts obtained from pawpaw due to presence of high anions of sodium, potassium, and calcium. This observation clearly supports the presence of alkaline anions like hydroxide and carbonate, among others [45], in nikkih, therefore leading to an alkaline $\mathrm{pH}$ as observed. Anions of sodium, potassium, and calcium decompose during the ashing process at high temperatures [45]. Generally, the M. acuminate sample had higher $\mathrm{pH}$ value than the Musa paradisiaca sample as shown in Table 3, which is due to differences in their composition [46].

Combustion time had a great impact on the $\mathrm{pH}$ value $(P<0.05)$ as varying the time affected the $\mathrm{pH}$ values significantly. The $\mathrm{pH}$ values of RwMa and $\mathrm{RwMp}$ increased with an increase in combustion time. The $\mathrm{pH}$ values of both samples of Mp90 and Ma90 increased slightly from 30 min to 60 mins, because the major components of $M$. acuminate and Musa paradisiaca residues are oxidized into the gaseous emission during prolonged combustion time, leaving behind metal oxides and other elemental components that form a good alkaline solution. The $\mathrm{pH}$ value increased with the increase in burning temperature and burning time for plantain peels, and it decreased from raw samples to boiled samples at all temperatures, while for banana it decreased from raw to boiled samples at all temperatures except $300^{\circ} \mathrm{C}$. This is due to the dilution. These results are similar with the reports of Uzodinma et al. [47], Udoetok [48], and Israel and Akpan [49] that ashes are usually alkaline $(\mathrm{pH}>10)$ because they are composed primarily of calcium carbonate, potassium chloride, and sodium chloride. The commercial sample had a $\mathrm{pH}$ value of 13.04, which is higher than all the $\mathrm{pH}$ values obtained here.

Potash yield depends on the type of plant material, the nature of soil where the plants grow, and the efficiency of extraction technology used [50]. From Table 4, it is observed that the potash content is in accordance with the potash content in the peels of some varieties of Nigeria grown plantain and banana as reported by Babayemi et al. [50] ranging from 69.0 to $81.9 \%$. The raw peels had a higher potash content than the boiled peels. This indicates that during the boiling pretreatment, some minerals were leached from the peels into the boiling water. Similar results were obtained by Adeparusi [51] when boiling Lima beans 
(Phaseolus lunatus L.). The potash content varied like that for all the samples except for RwMa burnt for 30 mins. The burning temperature, burning time, and dilution had little impact on the potash content $(P>0.05)$. When the peels are combusted slowly, they will not burn completely and this affects the concentration of the potash [52]. The above results are related to those reported by Babayemi et al. [37]. The potash content in the peels of some varieties of Nigeria grown plantain and banana ranged from 69.0 to $81.9 \%$. The commercial sample had a potash content value of $35.42 \pm 7.15 \%$, which is lower than the values obtained in this work.

Generally, it was observed that the pretreatment method and the combustion temperature and time had an effect on the alkaline and nonalkaline contents of the samples. The alkali content generally increased with increase in burning temperature. This is because the major components of plantain and banana residues are oxidized into gaseous emission during combustion, leaving behind metal oxides and other elemental components that form a good alkaline solution. The results obtained in this study are similar to those reported by Adewuyi et al. [13] who obtained alkali content within the range from 69.0 to $81.9 \%$. Since nonalkali content is derived from the value of alkali content, all the parameters which affected the alkali content also affected the nonalkali content. Furthermore, the boiling pretreatment method led to a lower alkalinity of nikkih as compared to the unboiled samples. This can be explained by the fact that biomass metallic salts are mostly soluble and the metallic salts are easily leached out during the boiling pretreatment [53].

The results in Table 6 indicated that emulsification index is significantly influenced by burning temperature and burning time while the potash source and dilution did not have a significant influence on the emulsification index $(P>0.05)$. Irrespective of the nikkih sample used, all samples showed a decrease in emulsification index after 48 hours. Also, similar results were obtained from the work done by Mbawala et al. [54]. In his research work, biosurfactants, nikkih and kanwa showed a decrease in emulsification index after 48 hours. The general decrease in emulsification index after 48 hours could be due to environmental stress such as gravitational separation, flocculation, coalescence, Ostwald ripening, and phase inversion as described by McClements [39]. The emulsification index of the raw samples was higher than those of the boiled samples since minerals were leached out during boiling. A higher emulsification was possible because interfacial tension was greatly reduced. Following the findings of Langnes et al. [55], chemical reactions between alkali and organic acids that exist in crude palm oil resulted in the formation of the surfactant and emulsification; therefore, the capillary pressures between the aqueous and oleic phases were reduced. When the aqueous phase and oil phase are in contact, the alkali and organic acids migrate into the interface forming surface active species [56].

The results in Table 7 indicated that foam capacity and foam stability of the potash on yellow achu soup, an oilwater emulsion, were significantly influenced by burning time $(P<0.05)$. Oil-water emulsion has a continuous phase formed of hydrophobic materials (oil) and water (globules) that make up the dispersed phase which is stabilized by an emulsifier [57]. According to Fennema [58], the foaming capacity is characterized as the interfacial area that can be created by a protein while the foaming stability is related to the ability to remain stable in the presence of gravitational or mechanical forces. In this study, proteins were absent; rather the emulsion formed as a result of the interaction between water and red palm oil using the alkali (nikkih) as an emulsifier was responsible for foaming (Ngwasiri et al., 2021). RwMa at $300^{\circ} \mathrm{C}$ had the highest foaming capacity but a lower foam stability, suggesting that the proportion of the emulsifiers used (as compared to the others) was not strong enough to overcome the surface tension at the oil-water interface, hence leading to the production of foams which are not very stable. This can be explained by the fact that the effectiveness of an emulsifier as a foaming agent appears to depend both on its effectiveness in reducing the surface tension of the foaming solution and on the magnitude of its intermolecular cohesive forces [59]. The burning time had a great impact on the foaming capacity and foam stability as the $p$ value was significant $(P<0.05)$. The potash source, burning temperature, and dilution factor had little impact on the foam capacity and foam stability $(P>0.05)$.

\section{Conclusions}

The results of this study showed that pretreating the peels and burning them at different temperatures and different times had an effect on the ash yield. The pretreated samples had lower ash yield than the ones not pretreated, and the samples combusted at higher temperatures and longer time had lower ash yield. All the process parameters (pretreatment, potash source, burning time, burning temperature, and dilution) had an impact on the physicochemical properties of nikkih. The results also showed that potash from the peels of Musa species is a very good source of the much needed alkali as a raw material for various alkali-based products. Ash and potash have compositions which vary with plant materials used. Varying all the process parameters had an influence on the functional properties of nikkih. Nikkih obtained from the raw peels had better emulsifying and foaming properties capable of stabilizing yellow achu soup than the boiled peels.

\section{Data Availability}

All data generated during this study are presented in the article.

\section{Conflicts of Interest}

The authors declare no conflicts of interest.

\section{Authors' Contributions}

Conceptualization and methodology are done by Ngwasiri Pride Ndasi and Adanmengwi Vivian Akah; software is provided by Ngwasiri Pride Ndasi and Adanmengwi Vivian Akah.; validation is carried out by Noumou Thierry, Dobgima John, and Ngwabie Martine Ngwa.; formal analysis is performed by Adanmengwi Vivian Akah; investigation is 
done by Ngwasiri Pride Ndasi and Adanmengwi Vivian Akah; resources are provided by Ngwasiri Pride Ndasi and Adanmengwi Vivian Akah and Ngwa Martine Ngwabie; data curation is done by Ngwasiri Pride Ndasi, Dobgima John F., and Adanmengwi Vivian Akah; original draft preparation is done by Ngwasiri Pride Ndasi and Adanmengwi Vivian Akah; review and editing is carried out by Wilson Agwanande A. Martin Benoit Ngassoum and Ejoh Richard Aba.; supervision is done by Ngwasiri Pride Ndasi. All authors have read and agreed on the published version of the manuscript.

\section{Acknowledgments}

The authors acknowledge the contribution of the Catholic University of Bamenda by providing access to their laboratory.

\section{References}

[1] M. G. Abiad and L. I. Meho, "Food loss and food waste research in the Arab world: a systematic review," Food Security, vol. 10, no. 2, pp. 311-322, 2018.

[2] FAO, "Food loss assessments: causes and solutions case studies in small-scale agriculture and fisheries subsectors. Kenya: banana, maize, milk, fish," Global Initiative on Food Loss and Waste Reduction - Save Food, FAO, Rome, Italy, 2014, http://www.fao.org/fileadmin/user_upload/save-food/ PDF/Kenya_Food_Loss_Studies.pdf.

[3] UNEP, Food Waste Index Report 2021, https://www.unep.org/ resources/report/unep-food-waste-index-report-2021 Available at, United Nations Environment Programme, Nairobi, Kenya, 2021, https://www.unep.org/resources/report/unepfood-waste-index-report-2021 Available at.

[4] I. Oluseun Adejumo and O. Adebukola Adebiyi, "Agricultural solid wastes: causes, effects, and effective management," Strategies of Sustainable Solid Waste Management, vol. 8, 2020.

[5] A. Vitorino de Souza Melaré, S. Montenegro González, K. Faceli, and V. Casadei, "Technologies and decision support systems to aid solid-waste management: a systematic review," Waste Management, vol. 59, pp. 567-584, 2017.

[6] J. F. Ayala-Zavala, V. Vega-Vega, C. Rosas-Domínguez et al., "Agro-industrial potential of exotic fruit byproducts as a source of food additives," Food Research International, vol. 44, no. 7, pp. 1866-1874, 2011.

[7] N. F. da Cruz, S. Ferreira, M. Cabral, P. Simões, and R. C. Marques, "Packaging waste recycling in Europe: is the industry paying for it?" Waste Management, vol. 34, no. 2, pp. 298-308, 2014.

[8] M. Mourad, "Recycling, recovering and preventing "food waste": competing solutions for food systems sustainability in the United States and France," Journal of Cleaner Production, vol. 126, pp. 461-477, 2016.

[9] H. F. Williams, T. Wikströma, M. Otterbringb, A. Löfgrenb, and Gustafssonb, "Reasons for household food waste with special attention to packaging," Journal of Cleaner Production, vol. 8, 2012.

[10] R. Luque and J. H. Clark, "Valorisation of food residues: waste to wealth using green chemical technologies," Sustainable Chemical Processes, vol. 1, no. 1, p. 10, 2013.

[11] N. B. D. Thi, C.-Y. Lin, and G. Kumar, "Waste-to-wealth for valorization of food waste to hydrogen and methane towards creating a sustainable ideal source of bioenergy," Journal of Cleaner Production, vol. 122, pp. 29-41, 2016.

[12] J. O. Okoye, N. O. Oranefo, and A. N. Okoli, "Comparative evaluation of the effects of palm bunch ash and trona on the liver of Albino rats," African Journal of Cellular Pathology, vol. 6, pp. 21-27, 2016.

[13] G. O. Adewuyi, N. O. Obi-Egbedi, and B. Jo, "Evaluation of ten different African wood species for potash production," International Journal of the Physical Sciences, vol. 3, pp. 63-68, 2008.

[14] C. O. Onyegbado, E. T. Iyagba, and O. J. Offor, "Solid soap production using plantain peels ash as source of alkali," Journal of Applied Sciences \& Environmental Management, vol. 6, pp. 73-77, 2004.

[15] H. Saidou, A. H. Hamzaoui, and A. Mnif, "Insoluble content, ionic composition, density, and X-ray diffraction spectra of 6 evaporites from Niger republic," Journal of Applied Chemistry, vol. 2015, Article ID 518737, 10 pages, 2015.

[16] T. Mianpeurem, M. Mbailao, N. Nambatinga, M. Yaya, and A. Ngarmadji, "Elemental composition of vegetable salts from ash of four common plants species from Chad," International Journal of Pharmacology, vol. 8, no. 6, pp. 582-585, 2012.

[17] A. M. Osano, E. R. Okong'o, N. Oyaro, and J. Kiptoo, "Compositional and structural characterization of three basic indigenous salts used in Kenya: a case study of "ebara", "magadi" and "lebek" crystalline salts," International Journal of Advanced Research in Science, Engineering and Technology, vol. 2, pp. 118-123, 2013.

[18] T. O. Ajiboye, Y. O. Komolafe, M. T. Yakubu, and S. M. Ogunbode, "Effects of trona on the redox status of cellular system ofmale rats," Toxicology and Industrial Health, vol. 3, no. 3, pp. 1-9, 2013.

[19] U. N. Onwuka and O. Okala, "Effects of selected salts on the cooking time, protein content and sensory properties of African yam beans and cowpeas," Food Service Technology, vol. 3, no. 1, pp. 3-7, 2003.

[20] T. L. Bergeson, C. Opio, and P. D. MacMillan, "Crop ash filtrate influence on cooking time and sensory preferences for dried black beans (Phaseolus vulgaris L.)," African Journal of Food Science, vol. 10, pp. 132-142, 2016.

[21] C. F. Doumta and C. Tchiégang, "Standardisation process to soften african locust beans seeds (parkia biglobosa benth) by a traditional method," Food Science, vol. 6, pp. 33-37, 2012.

[22] F. Akindejoye, T. B. Hammed, and M. K. C. Sridhar, "Potassium recovery potential of selected agroforestry and organic wastes in ibadan, Nigeria," European Scientific Journal, vol. 13, no. 6, pp. 1857-7881, 2017.

[23] I. C. Nnorom, O. Ebo, K. Nduka, J. C. Igwe, and C. Nwoko, "Metal contents of akanwu (Trona):Estimation of target hazard quotients (THQ) and dietary intake benefits and risks," ABSU International Journal of Environmental Science and Technology, vol. 2, pp. 275-289, 2012.

[24] H. Saidou, A. H. Hamzaoui, and A. Mnif, "Insoluble content, ionic composition, density, and X-ray diffraction spectra of 6 evaporites from the Niger republic," Journal of Applied Chemistry, vol. 10, 2015.

[25] S. R. Minka, C. M. F. Mbofung, C. Gandon, and M. Bruneteau, "The effect of cooking with kanwa alkaline salt on the chemical composition of black beans (Phaseolus vulgaris)," Food Chemistry, vol. 64, no. 2, pp. 145-148, 1999.

[26] M. B. Shaikh, K. M. Tarade, V. R. Bharadwaj, U. S. Annapure, and R. S. Singhal, "Effect of an alkaline salt (papadkhar) and its substitute (2:1 sodium carbonate:sodium bicarbonate) on acrylamide formation in papads," Food Chemistry, vol. 113, pp. 1165-1168, 2008. 
[27] T. O. Ajiboye, Y. O. Komolafe, M. T. Yakubu, and S. M. Ogunbode, "Effects of trona on the redox status of cellular system of male rats," Toxicology and Industrial Health, vol. 31, no. 2, pp. 179-187, 2015.

[28] F. K. Ngoualem, R. M. Nguimbou, and R. Ndjouenkeu, "Variability and functionalities of salts used in traditional african food preparations," Journal of Scientific Research and Reports, vol. 24, no. 3, pp. 1-14, 2019.

[29] P. N. Ngwasiri, B. I. Ekuh, N. T. Ngangmou et al., "Effect of incorporation of potash from Ficus carica fruit peel waste into potash (nikkih) from plantain peel waste as emulsifiers on the physico-chemical, functional properties, and acceptability of yellow achu soup," Asian Journal of Chemical Sciences, vol. 10, no. 3, pp. 1-10, 2021.

[30] F. Kégah Ngoualem, R. M. Nguimbou, A. Muhammad Khan, and R. Ndjouenkeu, "Chemistry and functionalities of lake deposits and plant-based salts used in food preparations: a review," Food Chemistry. Aug, vol. 321, Article ID 126674, 2020.

[31] J. A. Echeverri and O. E. Román-Jitdutjaaño, "Witoto ash salts from the Amazon," Journal of Ethnopharmacology, vol. 138, no. 2, pp. 492-502, 2011.

[32] J. A. Echeverri, O. Román, and S. Román, "La sal de monte: un ensayo de 'halofitogenografía' uitoto," in Imani Mundo: Estudios en la Amazonia Colombiana, C. Franky and C. Zárate, Eds., pp. 397-477, Unibiblos, Bogotá, Colombia, 2001.

[33] W. Phanice, K. Thomas, and N. Lenah, "Investigation of the transformation and effect of preparation method, storage conditions and time on iodine and iron (II) present in the reed salt," International Journal of Science and Research, vol. 5, 2016.

[34] M. C. Maguyon-Detras and S. C. Capareda, "Determining the operating condition for maximum bio-oil production from pyrolysis of Nannochloropsisoculata," Philippine Journal of Crop Science, vol. 42, no. 2, pp. 37-47, 2017.

[35] A. Kumar, "Extraction of caustic potash from coffee husk: Process optimization through response Surface methodology," Int. J. Chemical Science.vol. 11, no. 3, pp. 1261-1269, 2013.

[36] Vladamir. U. (1999). XX International Mineral Processing Congress. Germany.

[37] B. JO, K. T. Dauda, A. A. Kayode et al., "Determination of potash alkali and metal contents of ashes obtained from peels of some varieties of Nigeria Grown Musa species," Bioresource, vol. 5, pp. 1384-1392, 2010.

[38] Q. Liu, B. Kong, Y. L. Xiong, and X. Xia, “Antioxidant activity and functional properties of porcine plasma protein hydrolysate as influenced by the degree of hydrolysis," Food Chemistry, vol. 118, no. 2, pp. 403-410, 2010.

[39] D. J. Mcclements, Food Emulsion Principles, Practices, and Technique, CRC Press, Boca Raton, FL, USA, 2nd ed. edition, 2005.

[40] A. Garcia-Maraver, J. Mata-Sanchez, M. Carpio, and J. A. Perez-Jimenez, "Critical review of predictive coefficients for biomass ash deposition tendency," Journal of the Energy Institute, vol. 90, no. 2, pp. 214-228, 2017.

[41] V. Viena, Elvitriana, and S. Wardani, "Application of banana peels waste as adsorbents for the removal of CO2, NO, NOx, and SO2gases from motorcycle emissions," IOP Conference Series: Materials Science and Engineering, vol. 334, Article ID 012037, 2018.

[42] M. J. Dirbeba, A. Brink, D. Lindberg, M. Hupa, and L. Hupa, "Thermal conversion characteristics of molasses," ACS Omega, vol. 6, no. 33, pp. 21631-21645, 2021.
[43] F. Grau, H. Choo, J. Hu, and J. Jung, "Engineering behavior and characteristics of wood ash and sugarcane bagasse ash," Materials, vol. 8, no. 10, pp. 6962-6977, 2015.

[44] X.-T. He, T. J. Logan, and S. J. Traina, "Physical and chemical characteristics of selected U.S. municipal solid waste composts," Journal of Environmental Quality, vol. 24, no. 3, pp. 543-552, 1995.

[45] J. Gopalakrishnan, "Physico-chemical analysis of traditional vegetal salts obtained from three provinces of Papua New Guinea," Journal of Coastal Life Medicine, vol. 3, no. 6, pp. 476-485, 2015.

[46] U. S. Abubakar, K. M. Yusuf, I. Safiyanu, S. Abdullahi, S. R. Saidu, and G. T. Abdu, "Proximate and mineral composition of corn cob, banana and plantain peels," International Journal of Food Sciences \& Nutrition, vol. 1, no. 6, pp. 25-27, 2016.

[47] E. O. Uzodinma, J. C. Onweluzo, and S. N. Abugu, "Production and evaluation of instant emulsion base (Ncha) from oil palm biogenic waste," African Journal of Biotechnology, vol. 13, no. 49, pp. 4529-4535, 2014.

[48] I. A. Udoetok, "Characterization of ash made from oil palm bunch empty fruit bunches," International Journal of Environmental Sciences, vol. 1, no. 3, pp. 518-524, 2012.

[49] A. Israel and I. Akpan, "Mineral composition of ashed and charred palm (elaeis guineensis) bunch and plantain (Musa paradisiaca) peel," British Journal of Applied Science \& Technology, vol. 16, no. 5, pp. 1-9, 2016.

[50] B. JO, K. T. Duada, D. O. Nwude, and A. A. Kayode, "Evaluation of the composition and chemistry of ash and potash from various plant materials," A review J. Applied sciences.vol. 10, no. 16, pp. 1820-1824, 2010.

[51] E. O. Adeparusi, "Effect of processing on the nutrients and anti-nutrients of Lima zean (Phaseolus lunatus L.) flour," Nahrung-Food, vol. 45, no. 2, pp. 94-96, 2001.

[52] R. E. Kirk and V. R. Othmer, "Encyclopedia of chemical technology," Flavor Characterization to Fuel Cells, John Wiley \& Sons, New York, NY, USA, 4th edition, 1994.

[53] W. Xu, J. Wei, J. Chen et al., "Comparative study of waterleaching and acid-leaching pretreatment on the thermal stability and reactivity of biomass silica for viability as a pozzolanic additive in cement," Materials, vol. 11, no. 9, p. $1697,2018$.

[54] A. Mbawala, H. T. Mouafo, and R. R. Kom, "Antibacterial activity of Lactobacillus' biosurfactants against Pseudomonas spp. isolated from fresh beef," Biotechnology \& Bioscience.vol. 2, no. 1, pp. 7-22, 2015.

[55] G. L. Langnes, J. O. Jr Robertson, and G. V. Chelingarian, Secondary Recovery and Carbonate, p. 304, Reservoir Elsever, Amsterdam, The Netherlands, 1972.

[56] G. Z. Li, J. H. Mu, Y. Li, and S. L. Yuan, "An experimental study on alkaline/surfactant/polymer flooding systems using nature mixed carboxylate," Colloids and Surfaces A, vol. 173, no. 13, pp. 219-229, 2000.

[57] S. Akbari and A. H. Nour, "Emulsion types, stability mechanisms and rheology (2018): a review," International Journal for Innovative Research in Science \& Technology, vol. 1, no. 1, pp. 14-21, 2018.

[58] O. Fennema, Química de los Alimentos, Acribia, Zaragoza, Spain, 2a edition, 2000.

[59] F. Ricardo, D. Pradilla, J. C. Cruz, and O. Alvarez, "Emerging emulsifiers: conceptual basis for the identification and rational design of peptides with surface activity," International Journal of Molecular Sciences, vol. 22, no. 9, p. 4615, 2021. 